\title{
Morphotectonic Analysis of Burkh Anticline, North of Bastak (Zagros)
}

\author{
Mohammad Khalaj \\ Faculty of Science, Department of Geology, Payame Noor University, Tehran, Iran \\ Email: $\underline{\text { M khalaj@pnu.ac.ir }}$
}

Received 27 April 2015; accepted 7 June 2015; published 10 June 2015

Copyright (c) 2015 by author and Scientific Research Publishing Inc.

This work is licensed under the Creative Commons Attribution International License (CC BY). http://creativecommons.org/licenses/by/4.0/

(c) (i) Open Access

\begin{abstract}
Burkh Anticline having a length of $50 \mathrm{~km}$ and a width of $9 \mathrm{~km}$ is located $40 \mathrm{~km}$ to the north of Bastak City in Internal Fars zone along folded-thrust belt of Zagros. In order to assess the active tectonics in the area of study, morphotectonical indices such as valley index (V), ratio of valley floor to valley height $\left(\mathrm{V}_{\mathrm{f}}\right)$, channel sinuosity index $(\mathrm{S})$, mountain front faceting index $(\mathrm{F} \%)$ and mountain front sinuosity $\left(\mathrm{S}_{\mathrm{mf}}\right)$ are studied. These investigations show that the activity is not equal in various sections along Burkh Anticline and the central part of this anticline is the most active one.
\end{abstract}

Keywords

Anticline, Internal Fars Zone, Tectonics, Morphotectonic Indices, Folded-Trusted Belt

\section{Introduction}

The area of study is situated in the structural zone of Internal Fars within folded-thrust belt of Zagros between eastern longitudes of $54^{\circ}$ and $55^{\circ}$ and northern latitudes of $27^{\circ} 10^{\prime}$ and $27^{\circ} 30^{\prime}$. In terms of provincial divisions, the respective region is located in the west of Hormozgan Province and at an approximate distance of $40 \mathrm{~km}$ from Bastak City to the north. Having a N80W trend and an approximate length of $50 \mathrm{~km}$, Burkh Anticline mainly consists of Asmari-Jahrum limestone with the age of Oligocene-Miocene. Taking into account the location of the respective anticline in folded-thrust zone of Zagros, which is in turn a result of active convergence of Arabian and Eurasia plates along NNE-SSW direction [1] at a speed of $22 \mathrm{~mm} /$ year [2] up to $35 \mathrm{~mm} /$ year [3] this region is regarded among the tectonically active areas of Iran. The changes observed in the morphogeology of Burkh Anticline flanks have provided a good context for evaluation of tectonic activities along this anticline through morphometric analysis of the associated morphological forms. The major tectonic indices include topographic parameters and features $\left(\mathrm{V}, \mathrm{V}_{\mathrm{f}}, \mathrm{F} \%\right.$, and $\left.\mathrm{S}_{\mathrm{mf}}\right)$ as well as drainage system features (S), all of which are investigated in the present research. It is hoped that the findings of the current research would be helpful for re- 
searchers with regard to introducing the tectonic characteristics of this part of Iran.

\section{Depiction and Discussion}

\section{Research Methodology}

The needed information related to morphometric features of topographic forms of mountain front and steam drainage patterns were prepared from large-scale topographic maps $(1: 500,000)$ and geological maps with a scale of 1:100,000 besides SRTM data of the region. Then, the five morphometric indices were measured and the relative tectonic activity of the region was evaluated based on the acquired tectonic indices.

First, confirm that you have the correct template for your paper size. This template has been tailored for output on the custom paper size $(21 \mathrm{~cm} \times 28.5 \mathrm{~cm})$.

\section{Discussion}

\subsection{Morphometric Indices}

The landforms and deformations are described and mutually compared based on their size, height, and slope (dip). Nonetheless, the respective indices can be more accurately compared using quantitative measurements. The following indices were incorporated in this study:

\subsection{Mountain Front Sinuosity Index}

This index represents the equilibrium between the erosive forces causing mountain front irregularities and the effective tectonic forces which form the mountain front's straight line [4] and is defined as below (Figure 1):

$$
\mathrm{S}_{\mathrm{mf}}=\mathrm{L}_{\mathrm{mf}} / \mathrm{L}_{\mathrm{s}}
$$

To evaluate $S_{\mathrm{mf}}$, the mountain front in Burkh Anticline was divided into 6 sections. The respective sections are enumerated from west to east (Figure 2) and their corresponding information is included in Table 1.

Therefore, the mountain fronts influenced by active uplifiting are nearly straight and their $S_{\mathrm{mf}}$ indices roughly equal 1. But, if the uplifting intensity decreases or becomes zero, erosion process starts to form the sinusoidal mountain front which turns more irregular by the course of time.

Active mountain fronts exhibit $\mathrm{S}_{\mathrm{mf}}$ values larger than 1.4 [5]. Less active mountain fronts in which tectonic activity is still present suggest $S_{\mathrm{mf}}$ values in the range of 1.4 to 3 , and the values exceeding 3 belong to inactive faults. As seen in Table 1, $\mathrm{S}_{\mathrm{mf}}$ has its lowest values in sections $2,3,5$, and $6\left(\mathrm{~S}_{\mathrm{mf}}<1.4\right)$ indicating activity of the aforementioned sections whereas the respective index ranges between 1.4 and 3 in sections 1 and 4 demonstrating less activity compared to other parts of the anticline. However, their activity cannot be completely ignored.

\subsection{Mountain Front Faceting Index}

The percentage of mountain front faceting or F\% is defined as the ratio of summation of facet lengths in a mountain front $\left(\mathrm{L}_{\mathrm{f}}\right)$ to the corresponding straight line $\left(\mathrm{L}_{\mathrm{s}}\right)[6]$. (Figure 3)

$$
\mathrm{F} \%=\mathrm{L}_{\mathrm{f}} / \mathrm{L}_{\mathrm{s}}
$$

In general, large percentages for this index reflect high level of erosional activity in the mountain front [7]. To measure the F\% index, Burkh mountain front was again divided into 6 sections, enumerated from west to east (Figure 4). F\% values are included in Table 2.

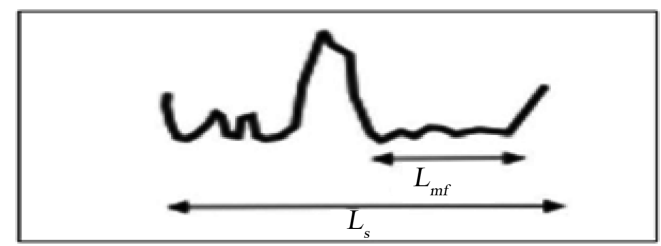

Figure 1. The factors affecting determination of mountain front sinuosity. 


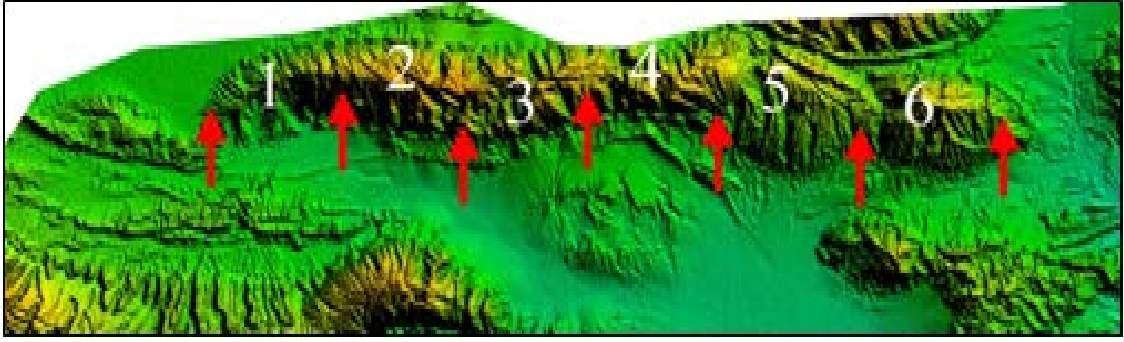

Figure 2. Division of the area of study to determine $\mathrm{S}_{\mathrm{mf}}$ index.

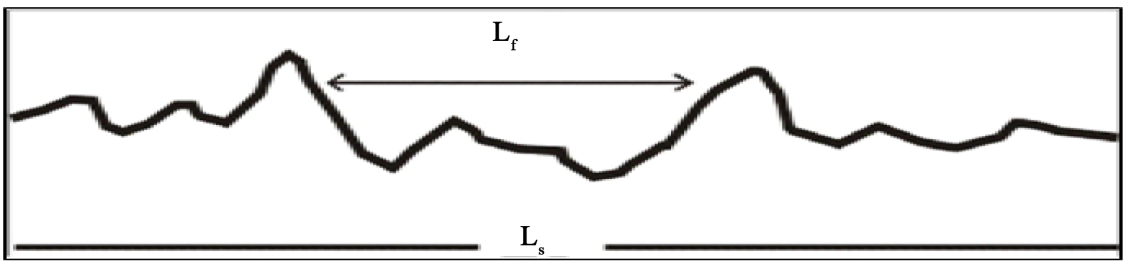

Figure 3. Facet index measurement procedure.

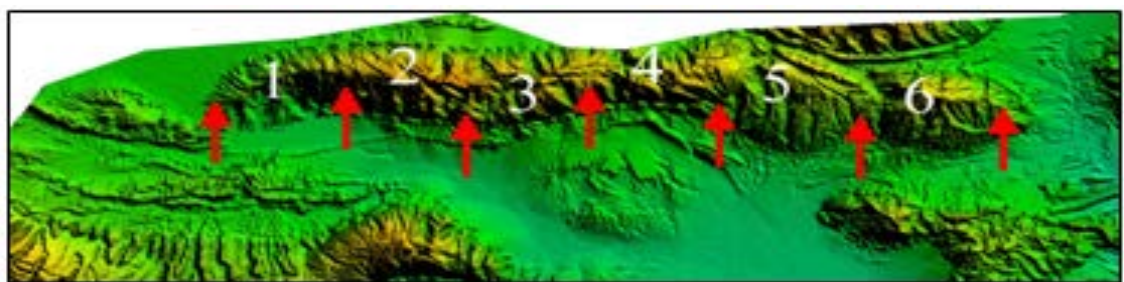

Figure 4. Davison of the area of study for determining F\% index.

Table 1. The values obtained for $\mathrm{S}_{\mathrm{mf}}$ index along Burkh Anticline.

\begin{tabular}{cccc}
\hline Front & $\mathrm{L}_{\mathrm{s}}$ & $\mathrm{L}_{\mathrm{mf}}$ & $\mathrm{S}_{\mathrm{mf}}$ \\
\hline 1 & 12,169 & 27,587 & 2.26 \\
2 & 11,430 & 12,357 & 1.08 \\
3 & 11,802 & 13,442 & 1.13 \\
4 & 12,023 & 21,298 & 1.77 \\
5 & 13,033 & 17,350 & 1.33 \\
6 & 13,112 & 17,545 & 1.33 \\
\hline
\end{tabular}

Table 2. The values obtained for F\% index along the anticline.

\begin{tabular}{cccc}
\hline Front & Lf & Ls & F\% \\
\hline 1 & 7615 & 12,169 & 0.63 \\
2 & 8990 & 11,430 & 0.79 \\
3 & 9534 & 11,802 & 0.81 \\
4 & 10,541 & 12,023 & 0.88 \\
5 & 9388 & 13,033 & 0.73 \\
6 & 9578 & 13,112 & 0.73 \\
\hline
\end{tabular}


The most active sections of this region lie in the middle part of the anticline based on the calculations i.e. the lowest faceting extent has been caused by streams in these sections. Yet, northwestern and southeastern sections have smaller values of F\% and assume lower relative uplifting activity according to the respective index. These results are to a great extent in accordance with mountain front sinuosity index results.

\subsection{Stream Channel Sinuosity Index (S)}

This index is derived from the following equation:

$$
\mathrm{S}=\mathrm{SL} / \mathrm{VL}
$$

where, SL is the length of steam trajectory and VL is the length of straight route.

Generally, sinuosity of a waterway increases with increasing slope. This sinuosity variation in turn shows the change and increase of tectonic activity rate. Unity value of this index signifies straightness of stream channel. Values between 1 and 1.5 suggest S-shape stream channel and those exceeding 1.5 represent meandering patterns.

As observed in Table 3, steams 8, 10, 11, and 13 which flow in the middle part of Brukh Anticline are more active than other parts of the anticline. Thus, tectonic forces have influenced along the route of these streams leading to larger uplifts compared to other streams. Morphological Indices of Valley Cross Section.

These indices include ratio of valley floor width to its height $\left(V_{f}\right)$ and valley ratio index $(V)$.

\subsection{Ratio of Valley Floor Width to Its Height}

Bull [4] considered the ratio of valley floor width to the average height of valley walls as a scale for the excavation strength of valley and defined $V_{\mathrm{f}}$ index accordingly:

$$
\mathrm{V}_{\mathrm{f}}=2 \mathrm{~V}_{\mathrm{fw}} /\left\{\left(\mathrm{E}_{\mathrm{ld}}-\mathrm{E}_{\mathrm{sc}}\right)+\left(\mathrm{E}_{\mathrm{rd}}-\mathrm{E}_{\mathrm{sc}}\right)\right\}
$$

In the equation above, $V_{\mathrm{f}}$ is the width of valley floor, $\mathrm{E}_{1 \mathrm{~d}}$ and $\mathrm{E}_{2 \mathrm{~d}}$ respectively represent the heights of left and right walls of the valley, and $\mathrm{E}_{\mathrm{ac}}$ is the elevation of valley floor from sea level (Figure 5).

To determine $V_{\mathrm{f}}$ index, 17 streams were chosen along Burkh Anticline and their cross sectional areas were analyzed. The respective streams are enumerated from west to east. Table 4 presents $V_{\mathrm{f}}$ values calculated for the valleys in the region. According to the values acquired for the valleys in the region, it can be inferred that the tectonic activities are not equal in different parts of the region, and, highly active and lowly active parts can be considered. Based on Table 4, it is seen that small values of $V_{\mathrm{f}}$ index belong to middle part of Burkh Anticline, suggesting further activity of this part compared to other parts.

\subsection{Valley Ratio (V index)}

One of the factors affecting morphology of the stream valley is the erosional mechanism of its walls. This index equals the ratio of valley area to the area of the semi-circle with an equivalent radius of valley depth and is derived from the following formula: $\mathrm{V}=\mathrm{Av} / \mathrm{Ac}$, where $\mathrm{Av}$ is the area of the generated valley and Ac is the area of the semi-circle.

According to Table 5, the minimum value of $\mathrm{V}$ ratio belongs to the central parts and also the southeastern end of Burkh Anticline. V values smaller than 1 indicate greater activity of the valleys.

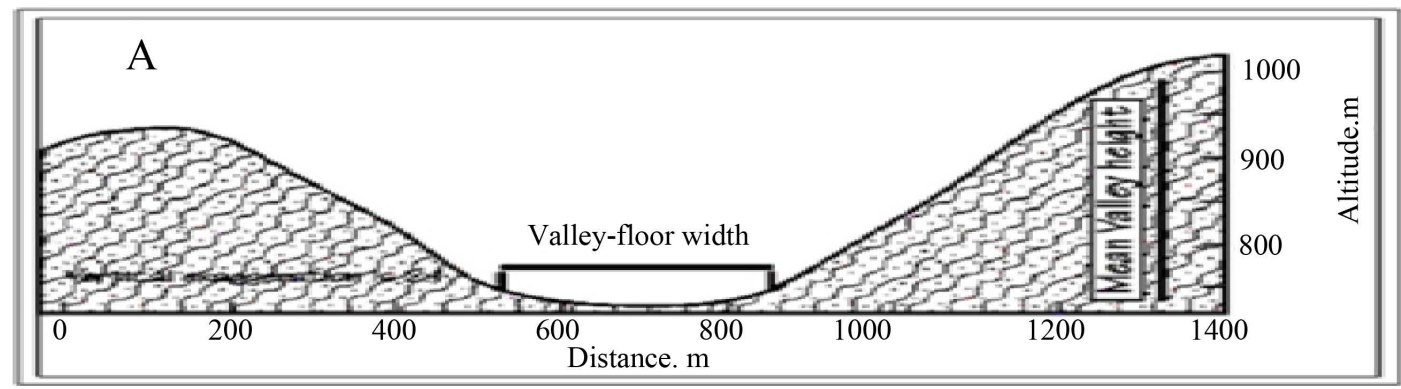

Figure 5. Vf index measurement procedure. 
Table 3. S values for main streams of Burkh Anticline Region.

\begin{tabular}{|c|c|c|c|c|c|}
\hline Stream & Longitude & Latitude & SL & VL & $\mathrm{S}$ \\
\hline 1 & $27^{\circ} 28^{\prime} 6.6221^{\prime \prime N}$ & $54^{\circ} 16^{\prime} 2.9884^{\prime \prime} \mathrm{E}$ & 5348 & 4678 & 1.143224 \\
\hline 2 & $27^{\circ} 27^{\prime} 40.4597 " \mathrm{~N}$ & $54^{\circ} 17^{\prime} 30.9107^{\prime \prime E}$ & 6468 & 5651 & 1.144576 \\
\hline 3 & $27^{\circ} 26^{\prime} 40.5219^{\prime \prime} \mathrm{N}$ & $54^{\circ} 18^{\prime} 12.4030^{\prime \prime} \mathrm{E}$ & 6039 & 4852 & 1.244641 \\
\hline 4 & $27^{\circ} 26^{\prime} 18.8733 " \mathrm{~N}$ & $54^{\circ} 19^{\prime} 9.1591^{\prime \prime} \mathrm{E}$ & 7332 & 5739 & 1.277574 \\
\hline 5 & $27^{\circ} 25^{\prime} 17.7748 " \mathrm{~N}$ & $54^{\circ} 20^{\prime} 16.0071 " \mathrm{E}$ & 5714 & 5038 & 1.122324 \\
\hline 6 & $27^{\circ} 25^{\prime} 55.9342^{\prime \prime N}$ & 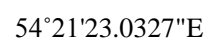 & 4771 & 4251 & 1.122324 \\
\hline 7 & $27^{\circ} 25^{\prime} 3.8472 " \mathrm{~N}$ & $54^{\circ} 22^{\prime} 37.7936^{\prime \prime} \mathrm{E}$ & 5721 & 5038 & 1.13418 \\
\hline 8 & $27^{\circ} 25^{\prime} 33.0935^{\prime \prime N}$ & $54^{\circ} 24^{\prime} 37.8266^{\prime \prime} \mathrm{E}$ & 9518 & 6677 & 1.42549 \\
\hline 9 & $27^{\circ} 24^{\prime} 29.0641 " \mathrm{~N}$ & $54^{\circ} 24^{\prime} 37.8266^{\prime \prime} \mathrm{E}$ & 5988 & 4863 & 1.231339 \\
\hline 10 & $27^{\circ} 25^{\prime} 28.9988^{\prime \prime N}$ & $54^{\circ} 26^{\prime} 15.5588^{\prime \prime} \mathrm{E}$ & 11,321 & 7710 & 1.468353 \\
\hline 11 & $27^{\circ} 23^{\prime} 15.8691 " \mathrm{~N}$ & $54^{\circ} 27^{\prime} 10.3702^{\prime \prime E}$ & 6393 & 4481 & 1.42669 \\
\hline 12 & $27^{\circ} 25^{\prime} 22.2117^{\prime \prime N}$ & $54^{\circ} 28^{\prime} 7.6746^{\prime \prime} \mathrm{E}$ & 10,276 & 8220 & 1.250122 \\
\hline 13 & $27^{\circ} 23^{\prime} 15.9971 " \mathrm{~N}$ & $54^{\circ} 30^{\prime} 9.4074^{\prime \prime} \mathrm{E}$ & 12,035 & 8074 & 1.490587 \\
\hline 14 & $27^{\circ} 24^{\prime} 1.0153 " ’ \mathrm{~N}$ & $54^{\circ} 31^{\prime} 48.5984 " \mathrm{E}$ & 20,805 & 15,824 & 1.314775 \\
\hline 15 & $27^{\circ} 25^{\prime} 44.0885^{\prime \prime N}$ & $54^{\circ} 33^{\prime} 15.2768 " \mathrm{E}$ & 8274 & 6519 & 1.269213 \\
\hline 16 & $27^{\circ} 25^{\prime} 15.2343^{\prime \prime N}$ & $54^{\circ} 34^{\prime} 22.9648^{\prime \prime} \mathrm{E}$ & 3509 & 2900 & 1.21 \\
\hline 17 & $27^{\circ} 24^{\prime} 8.5866 " \mathrm{~N}$ & $54^{\circ} 36^{\prime} 58.1390 " \mathrm{E}$ & 18,812 & 14,957 & 1.257739 \\
\hline
\end{tabular}

Table 4. The values obtained for $\mathrm{V}_{\mathrm{f}}$ index along the anticline.

\begin{tabular}{ccccccc}
\hline Valley & Coordinates & $\mathrm{E}_{\mathrm{rd}}$ & $\mathrm{E}_{\mathrm{sd}}$ & $\mathrm{E}_{\mathrm{sc}}$ & $\mathrm{V}_{\mathrm{fw}}$ & $\mathrm{V}_{\mathrm{f}}$ \\
\hline 1 & $27^{\circ} 28^{\prime} \mathrm{N}, 54^{\circ} 16^{\prime} \mathrm{E}$ & 558.58 & 640 & 520 & 349.88 & 4.412662379 \\
2 & $27^{\circ} 27^{\prime} \mathrm{N}, 54^{\circ} 17^{\prime} \mathrm{E}$ & 657.21 & 598.4 & 520 & 180 & 1.669681369 \\
3 & $26^{\circ} 26^{\prime} \mathrm{N}, 54^{\circ} 18^{\prime} \mathrm{E}$ & 625 & 595.17 & 513 & 140 & 1.44203533 \\
4 & $27^{\circ} 26^{\prime} \mathrm{N}, 54^{\circ} 19^{\prime} \mathrm{E}$ & 715.29 & 633.55 & 575 & 230 & 2.313417823 \\
5 & $27^{\circ} 25^{\prime} \mathrm{N}, 54^{\circ} 20^{\prime} \mathrm{E}$ & 713.17 & 712.69 & 789 & 15 & 0.130514226 \\
6 & $27^{\circ} 25^{\prime} \mathrm{N}, 54^{\circ} 21^{\prime} \mathrm{E}$ & 840 & 810.44 & 700 & 150 & 1197891711 \\
7 & $27^{\circ} 25^{\prime} \mathrm{N}, 54^{\circ} 22^{\prime} \mathrm{E}$ & 852 & 756.79 & 646 & 12 & 0.075759967 \\
8 & $27^{\circ} 25^{\prime} \mathrm{N}, 54^{\circ} 24^{\prime} \mathrm{E}$ & 928 & 913.1 & 755 & 15 & 0.090607067 \\
9 & $27^{\circ} 24^{\prime} \mathrm{N}, 54^{\circ} 24^{\prime} \mathrm{E}$ & 960.78 & 785 & 764 & 15 & 0.137696792 \\
10 & $27^{\circ} 25^{\prime} \mathrm{N}, 54^{\circ} 26^{\prime} \mathrm{E}$ & 870 & 860 & 735 & 20 & 0.153846154 \\
11 & $27^{\circ} 23^{\prime} \mathrm{N}, 54^{\circ} 27^{\prime} \mathrm{E}$ & 836 & 715 & 666 & 13 & 0.118721461 \\
12 & $27^{\circ} 25^{\prime} \mathrm{N}, 54^{\circ} 28^{\prime} \mathrm{E}$ & 870 & 838 & 773 & 20 & 0.24691358 \\
13 & $27^{\circ} 23^{\prime} \mathrm{N}, 54^{\circ} 30^{\prime} \mathrm{E}$ & 829 & 824 & 682 & 17 & 0.117647059 \\
14 & $27^{\circ} 24^{\prime} \mathrm{N}, 54^{\circ} 31^{\prime} \mathrm{E}$ & 900 & 826 & 745 & 30 & 0.254237288 \\
15 & $27^{\circ} 25^{\prime} \mathrm{N}, 54^{\circ} 33^{\prime} \mathrm{E}$ & 904 & 936 & 753 & 25 & 0.149700599 \\
16 & $27^{\circ} 25^{\prime} \mathrm{N}, 54^{\circ} 34^{\prime} \mathrm{E}$ & 881 & 240 & 842 & 25 & 0.364963504 \\
\hline & $27^{\circ} 24^{\prime} \mathrm{N}, 54^{\circ} 36^{\prime} \mathrm{E}$ & 1100 & 1020 & 744 & 15 & 0.47468354 \\
\hline
\end{tabular}


Table 5. The values evaluated for $\mathrm{V}$ index along the anticline.

\begin{tabular}{|c|c|c|c|c|c|}
\hline Valley & Longitude & Latitude & $\operatorname{Av}(m)^{2}$ & $\mathrm{Ac}(\mathrm{m})^{2}$ & $\mathrm{~V}$ \\
\hline 1 & $27^{\circ} 28^{\prime} 6.6221 " \mathrm{~N}$ & $54^{\circ} 16^{\prime 2} 2.9884^{\prime \prime} \mathrm{E}$ & 190.1072 & 35,636 & 0.53 \\
\hline 2 & $27^{\circ} 27^{\prime} 40.4597 " \mathrm{~N}$ & $54^{\circ} 17^{\prime} 30.9107^{\prime E}$ & 8753.75 & 18,625 & 0.47 \\
\hline 3 & $27^{\circ} 26^{\prime} 40.5219 " \mathrm{~N}$ & $54^{\circ} 18^{\prime} 12.4030^{\prime E}$ & 10139.52 & 21,124 & 0.48 \\
\hline 4 & $27^{\circ} 26^{\prime} 18.8733^{\prime \prime N}$ & $54^{\circ} 19^{\prime} 9.1591 " \mathrm{E}$ & 6226.27 & 10,207 & 0.61 \\
\hline 5 & $27^{\circ} 25^{\prime} 17.7748 " \mathrm{~N}$ & $54^{\circ} 20^{\prime} 16.0071^{\prime \prime E}$ & 20125.67 & 49,087 & 0.41 \\
\hline 6 & $27^{\circ} 25^{\prime} 55.9342 " \mathrm{~N}$ & $54^{\circ} 21^{\prime 2} 23.0327^{\prime \prime E}$ & 16725.72 & 38,013 & 0.44 \\
\hline 7 & $27^{\circ} 25^{\prime} 3.8472 " \mathrm{~N}$ & $54^{\circ} 22^{\prime} 37.7936^{\prime \prime E}$ & 18010.72 & 34,636 & 0.52 \\
\hline 8 & $27^{\circ} 25^{\prime} 33.0935^{\prime \prime N}$ & $54^{\circ} 24^{\prime} 37.8266^{\prime \prime E}$ & 4763262 & 113,411 & 0.42 \\
\hline 9 & $27^{\circ} 24^{\prime} 29.0641 " \mathrm{~N}$ & $54^{\circ} 24^{\prime} 37.8266^{\prime \prime E}$ & 34346.52 & 66,051 & 0.52 \\
\hline 10 & $27^{\circ} 25^{\prime} 28.9988^{\prime \prime N}$ & $54^{\circ} 26^{\prime} 15.5588^{\prime \prime} \mathrm{E}$ & 21184.35 & 57,255 & 0.37 \\
\hline 11 & $27^{\circ} 23^{\prime} 15.8691 " \mathrm{~N}$ & $54^{\circ} 27^{\prime} 10.3702^{\prime \prime E}$ & 8638.3 & 7853 & 1.1 \\
\hline 12 & $27^{\circ} 25^{\prime} 22.2117 " \mathrm{~N}$ & $54^{\circ} 28^{\prime} 7.6746^{\prime \prime} \mathrm{E}$ & 6618.99 & 15,393 & 0.43 \\
\hline 13 & $27^{\circ} 23^{\prime} 15.9971 " \mathrm{~N}$ & $54^{\circ} 30^{\prime} 9.4074^{\prime \prime} \mathrm{E}$ & 23117.85 & 66,051 & 0.35 \\
\hline 14 & $27^{\circ} 24^{\prime} 1.0153^{\prime \prime N}$ & $54^{\circ} 31^{\prime} 48.5984^{\prime \prime E}$ & 5541.41 & 11,309 & 0.49 \\
\hline 15 & $27^{\circ} 25^{\prime} 44.0885 " \mathrm{~N}$ & $54^{\circ} 33^{\prime} 15.2768^{\prime \prime E}$ & 22619.2 & 70,685 & 0.32 \\
\hline 16 & $27^{\circ} 25^{\prime} 15.2343 " \mathrm{~N}$ & $54^{\circ} 34^{\prime} 22.9648^{\prime \prime E}$ & 3546.24 & 5541 & 0.64 \\
\hline 17 & $27^{\circ} 24^{\prime} 8.5866 " \mathrm{~N}$ & $54^{\circ} 36^{\prime} 58.1390^{\prime \prime} \mathrm{E}$ & 76576.11 & 196,349 & 0.39 \\
\hline
\end{tabular}

\section{Conclusions}

When several indices are utilized for classification and analysis of tectonic activities, the results will be more meaningful and reasonable than applying only one index. This approach was followed for assessment of Burkh Anticline. Analysis of morphometric indices led to following conclusions:

1) High value of mountain front faceting index in the middle parts and relative low value of the same index in the northwestern and southeastern parts, in addition to small value of $S_{m f}$ index in the middle parts of the anticline suggest larger tectonic activity of the central parts of the anticline.

2) The maximum values of stream channel sinuosity index are observed in the middle part of the anticline.

3) According to the values obtained for $V_{f}$ and $V$ indices, it can be deduced that small values of these two indices belong to the middle part of the anticline manifesting greater activity of the respective part compared to other parts. Overall, it can be stated that investigation of geomorphological phenomena and different morphometric indices in the region confirm high and intense tectonic activity in the middle part of Burkh Anticline.

\section{References}

[1] Tatar, M., Hatzfeld, D., Martinod, J., Walpersdorf, A., Ghafori-Ashtiany, M. and Chéry, J. (2002) The Present-Day Deformation of the Central Zagros from GPS Measurements. Geophysical Research Letters, 29, 1927-1930. http://dx.doi.org/10.1029/2002GL015427

[2] Bayer, R., Shabanian, E., Regard, V., Vernant, P., Nilforoushan, F., et al. (2002) Active Deformation in Zagros Makran Transition Zone Inferred from GPS; Tectonic and Seismological Measurement. Vol. 83, Eos Trans. AGU, Fall Meet., Suppl., Abstract S622B-1188.

[3] DeMets, C., Gordon, R.G., Argus, D.F. and Stein, S. (1990) Current Plate Motion. Geophysical Journal International, 101, 425-478. http://dx.doi.org/10.1111/j.1365-246X.1990.tb06579.x

[4] Bull, W.B. and McFadden, L. (1977) Tectonic Geomorphology of North and South of the Garlock Fault, California. In: Dohring, D.O., Ed., Geomorphology in Arid Regions, Publ. in Geomorphology, State University of New York, Binghamton, 115-138.

[5] Rockwell, T., Keller, E. and Jhonson, D. (1984) Tectonic Geomorphology of Alluvial Fans and Mountain Fronts Near Ventura, California. In: Morisawa, M. and Hack, T.J., Eds., Tectonic Geomorphology, Publ. in Geomorphology, State 
Union of New York, Binghamton, 183-207.

[6] Wells, S.G., Bullard, T.F., Menges, C.M., Drake, P.G., Karas, P.A., Kelson, K.I., Ritter, J.B. and Wesling, J.R. (1988) Regional Variations in Tectonic Geomorphology along a Segmented Convergent Plate Boundary Pacific Coast of Costa Rica. Geomorphology, 1, 239-265.

[7] Hancok, P.L. (1994) Continental Deformation. Chapter 18, Neotectonics, Pergamon Press, Oxford, 180-198. 